DOI: 10.31866/2617-2674.4.1.2021.235094

UDC 77.041.5-055.2(091)

\title{
FEMALE PORTRAIT IN PHOTOGRAPHY ART: FROM AUTHENTICITY TO MODERNITY
}

\section{Svitlana Kotliar1a, Iryna Zaspa ${ }^{2 a}$}

${ }^{1}$ Honoured Art Worker of Ukraine, Professor of the Television Journalism and Acting Department; e-mail: ilanit1925@gmail.com; ORCID: 0000-0002-4855-8172

${ }^{2}$ Master's Student at the Cinema and Television Arts Department; e-mail: duymovochkaira@gmail.com; ORCID: 0000-0003-0648-1901

${ }^{a}$ Kyiv National University of Culture and Arts, Kyiv, Ukraine

\section{Keywords:}

portrait;

female portrait; the art of photography; photography;

art

\begin{abstract}
The purpose of the research is to analyze female photo portrait, the concept of female beauty in photography, the history of the origin and formation of female portrait in photography. Moreover, the aim was to trace the common and distinct features of a female portrait from the past to nowadays. It was decided to establish a role of female photo portrait in the art of photography, to prove its peculiarity and importance. The research methodology consists of the following parts: theoretical analysis of the female beauty concept in the photo portrait, history of female portrait development in photography, empirical - study of relationships between female portraits of different times, comparative - comparison of modern and authentic portraits. In the course of cognitive synthesis and generalization of distinctive and similar features of female photo portraits of different times, special features of the female portrait were determined. Scientific novelty. For the first time, the history and formation of female photo portrait from authenticity to the nowadays were analyzed. The analysis was conducted based on photo portraits researches of different times. A detailed analysis of factors influencing the formation of this genre of photography was carried out. With the help of the theoretical analysis, the factors influencing the development of the female photo portrait were determined, its specifics and features were outlined. Conclusions. In the course of the article, we analyzed female portrait in photography and the concept of female beauty in different periods. With the help of the analysis of the history of development and formation of the female portrait photography genre, its role in the art of photography has been established. Peculiarities of female photo portrait as a genre of the art of photography were determined. Its peculiarity and importance have been proved. The factors influencing the concept of female beauty in photography, the development of female portrait and its features have been generalized.
\end{abstract}

\section{For citation:}

Kotliar, S. and Zaspa, I. (2021). Female portrait in photography art: from authenticity to modernity Bulletin of Kyiv National University of Culture and Arts. Series in Audiovisual Arts and Production, 4(1), pp.84-96. 


\section{Problem statement}

The female portrait has studied not enough. One of the main genres of art is a portrait. Since ancient times both women and men have tried to preserve their images through the portrait. Portraits of different times differ from each other, because they are a reflection of the period in which they were created, acquiring characteristic features. Thus, the portrait becomes one of the tools through which you can explore the views of preferences and life of people of different eras. As for the male portrait, we can still find a study of it because historically it has happened that men for a long time in history held leadership positions that were inaccessible to women and somehow went down in history. The male portrait was of interest to scientists and researchers. For example, these are pharaohs in ancient Egypt, kings, or presidents in the modern world. However, at the same time, female portraits, and with the advent of photography - photo portraits became the subject of study much less frequently. This is the problem of not paying enough attention to female portraits and their insufficient study.

According to Volkov-Lannit (1974, p.14), "a photo portrait is an objective document of life". In this capacity, it can serve as a material for special research and even a textbook.

As women are an integral part of the structure in any ethnic group's life, and in some, such as Ukrainian one, occupies one of the main places. In addition, women are an effective subject, carrier and translator of the traditional authenticity of ethnoculture, mainly - the system of values of the people and socio-cultural norms. That makes the study relevant and valuable. That will allow to analyze the history and formation of female photography from authentic to nowadays based on the study of portraits of different times, to conduct a detailed analysis of factors influencing the formation of this genre of photography, to outline its specifics and identify features.

\section{The analysis of recent researches and publications}

After conducting a research on the topic "female portrait in the art of photography: from authenticity to nowadays", it has been found that there are no books on the given topic, but there are those that partially describe this topic and articles. The vast majority of information was found in works of such authors: Lewinsky J. and Magnus M. (1982), Pavlova T. (2019), Volkov-Lannit L. F. (1974). After familiarization with the works of these authors, it becomes clear that each of them covers issues that are observed in their field of activity or related to it. For example, Levinsky J. is a photographer by profession and describes the specifics of creating a photo portrait and photography in general in his book. However, from the amount of information, we can distinguish the facts about female portraits. The same can be said about Volkov-Lannit L. F., who widely describes the art of photo portraiture, thus covering the selected topic of the article.

The purpose of the research is to analyze female portrait, the concept of female beauty in photography, the history of the emergence and formation of the female portrait in photography, to trace the development of female photo portrait from the past till the present. Moreover, the aim was to identify and analyze on the basis of comparison and analysis similarities and differences between the 
female portrait of different times. It was decided to compare a woman's authentic photo portrait and a modern one. Furthermore, it was aimed to establish the role of the female photo portrait in the art of photography and to prove that its peculiarity is important.

\section{Main research material}

Lewinsky J. and Magnus M. (1982a) tried to describe a genre such as a portrait and photo-portrait and admitted that the dictionary interprets the word "portrait" as "a reproduction of certain features of a particular person as seen by the artist".

At all times, people's attention was drawn to the appearance, character and lifestyle of others. That creates a desire to express impressions, in other words, to create a portrait.

As the authors Lewinsky J. and Magnus M. (1982a) note: "portraitists are the first and most accurate observers who notice the properties of human character, manifestations of temperament, habits and gestures, movements and manner of speaking; highlight the individual features of each model".

The predecessor of the photo portrait was a picturesque portrait. The oldest of the most picturesque images of this genre that have lasted till modern days are paintings on Egyptian sarcophagi of the Roman era.

They date from the 1 st -2 nd centuries AD. By the beginning of the 16th century, the masters of the late Renaissance developed their skills in the art of portraiture to the highest perfection. Nevertheless, customers demanded their appearance to be noble, elegant and haughty, and artists had to satisfy such vanity. As a result, most artists suffered from a lack of creative freedom.
Everything changed for the better in the 19th, but by that time photography had already begun to displace the picturesque portrait. Miniature artists were the first to feel the seriousness of the competition. The prophecy: "From this day painting perished", uttered by the artist LaRoche in 1839 at the official presentation of the discovery, came true in full for the artists of that time (Sofiia, 2019).

The French artist Matisse told I. G. Ehrenburg: "Do you know to whom modern painting owes much? Daguerre, Niepce. A descriptive painting was never needed again after photographing an image. No matter how hard an artist tries to be objective, a photographic lens always wins. To judge what Engr was like, I have to look at his self-portrait, the portrait of David, other artists, each of them is different and I don't know what mouth Engr had. However, I know Hugo from daguerreotypes and photographs" (Volkov-Lannit, 1974, p.15).

"A true photo-portrait artist is not a copy of the external physical features of a prototype," said Volkov-Lannit L. F. (1974, p.15). While creating an image of a particular person with the help of technical, the artist expresses his understanding of another's character. In addition to the individuality of the prototype, there is the individuality of the performer of the portrait, which is manifested in the personal attitude to the depicted character.

The woman's first portrait was a photo of Dorothy Catherine Draper, the 33-year-old elder sister of John William Draper, an American physician, chemist, historian, philosopher and photographer. The picture was taken in early 1840. Draper designed a camera of his own design and set up several experiments to improve Daguerre's chemical process after he found out about Daguerre's discovery. 
The picture was taken on the roof of New York University on a cloudy day. Exposure lasted 65 seconds. Dorothy's face was covered with a layer of flour in order to give more contrast to the photo. Interesting to know that in 1840 a woman could get into the walls of New York University only if accompanied by a man, unfortunately (The first-ever female portrait, 2018).

Daguerreotypes became early photographic images. It was difficult to create portraits in the technique of daguerreotype. This method required a very long exposure - half an hour. However, chemicals, lenses and cameras were soon improved, and exposure time in sunny weather was reduced to 1-2 minutes. The daguerreotype had another serious drawback: each frame was unique - it was not imprinted. The first negative-positive photographic process - calotype was invented in 1839 by the Englishman William Henry Fox Talbot. The calotype was used by the world's first great masters of portrait photography, Scots David Octavius Hill and Robert Adamson. (Sofiia, 2019).

Robert Adamson left about 2,500 "calotypes", mostly those were portraits taken by him over 5 years. The women and girls in Robert Adamson's portraits appear in the images of the fashion of that time: long layered dresses, hats, lace, exquisite jewellery and aristocratic hairstyles. Many photos were taken indoors in static positions, and there are full-size photos. The next significant event that influenced portrait photography took place in 1851 . Frederick Scott Archer invented the wet collodion method, in which a negative image was recorded on a glass plate. This method not only made it possible to reproduce the image in unlimited quantities but also significantly reduced the exposure time (Sofiia, 2019).
The wet collodion method made it too difficult to take full-scale images, as the photographic plate had to be sensitized and developed until it dried in the laboratory. But it made it much easier to work with a portraitist in a studio.

In the third quarter of the 19th century, the genre of portrait photography developed rapidly, and on both sides of the Atlantic Ocean appeared a whole galaxy of great artists. In America, Matthew Brady, Albert Sands Southworth and Josiah Johnson House were nominated, in France the most popular were Etienne Carrzy, Camille Sylvie and Nadar, in England - Oscar Gustav Raylander. In England, in 1864-1875, the incomparable Julia Margaret Cameron reigned supreme (Julia Margaret Cameron - English photographer of the Victorian era, 2016).

Let us dwell in more detail on the figure of Julia Margaret Cameron, as a representative of the Victorian era in photography, which often featured female images. There are many photos of famous people in her works, but mostly ordinary people became her models. In 1874, she collaborated with Alfred Tennis and created photo illustrations for a popular series of poems about King Arthur.

If you take a look at some photo portraits, they may resemble paintings. Because of this, Margaret received great respect among proto-Raphaelite artists. The portraits seem to be painted with oil paints, the women in the photo often resemble images from icons, especially the image of the Madonna. That is not surprising, because at that time one of the main missions of women was giving birth to children. In some of her photos, women, girls and children have wings or attributes of muses from Greek mythology, which suggests that Margaret was already creating an artistic photograph 
filled with the plot. Models in female portraits have a distinct face and the attention was focused on eyes. Often it is emphasized by some props, or an accessory, such as a hair ornament or fabric, sometimes we find flowers and things from women's life as props, sometimes the focus may not be on the model. The photographer conveyed the mood and character of the models through such accents. The clothes of women in a frame depend on an idea, if it is an ordinary portrait, then women dressed in clothes typical for that era. If it is an art photo, we can observe draping with fabrics reminiscent of antiquity, which was later reflected in the Renaissance. Thus, we can conclude that Margaret in her photographs imitated the artists of the Renaissance. For which it was loved by protoRaphaelite artists. Contemporaries of photography and some critics considered her soft focus on photographs a simple technical error, but modern critics believe that Julia Cameron made a great contribution to the development of the art of photography and in particular female portraiture (Julia Margaret Cameron English photographer of the Victorian era, 2016).

However, with the clear exception of Julia Margaret Cameron, who neglected all canons with her grand plans, and Lewis Carroll, who sought immediacy and ease, nineteenth-century photographers mostly borrowed the techniques of portrait painting. Mostly, they followed a pattern and created static, slightly heavier images.

Lewis Carroll was particularly interested in technical innovations and improvements. Thanks to the acquaintance with the archbishop, the doors of the Lambeth Palace opened before him. His frame usually included either children or celebrities. For example, a portrait of Lewis
Carroll: Grace Denman, daughter of Chief Justice Denman, 1864 or the English feminist poetess, one of the best poets of the Victorian era, Christina Georgina Rossetti.

Another frequent model was Alice Liddell, daughter of Henry Liddell, a classic philologist and dean of one of Oxford's colleges. It is reflected in 20 photographs of the writer. Carroll's work Alice in Wonderland is dedicated to her. Let's try to analyze the main characteristics of the beauty of the female photo portrait of that time on the basis of photo portraits of Lewis Carroll. In this case, those are young women. In the pictures, we see casual models that can look like paintings. "The Carroll photographer paid a lot of attention to the composition. No coincidence, no improvisation, everything was thought out to the smallest detail, especially the position of hands. His photos are more like icons, where there is nothing superfluous and everything is thought out. For the same reason, Carroll prefers to photograph his models in full length: so, it seemed more expressive to him" (Sova, 2019).

However, much attention was paid to face and gaze, which is often aimed directly at the lens. Carroll photographed models both in their usual position and created the author's plot photos, transforming the girls into different images, but leaving each one. We can conclude that the concept of beauty according to Carroll at that time contained the grace of the figure, a certain mystery, a clear face with a clear look, which was only framed by a certain outfit but did not draw emphasis on itself.

A typical portrait of that time looked like this: a well-lit model, usually in a chair, with a three-quarter turn, a drape or a picturesque background that mimics a natural setting. Except for some in- 
spired innovators and photorealists, this interpretation is more like painting, with some modifications and improvements that persisted in the practice of many portrait painters until the middle of the twentieth century. The vast majority of photographers of the twentieth century concerning portrait photography put in the first place two requirements: to take portraits only in the studio and to give the lighting a partially mystical character.

Let's try to compare the development of women's photography in Ukraine. The art of photography comes to Ukraine from abroad. Consider the work of French photographer Jean Raoul, which he made during his travels through Ukraine in 1860-1880 (Archives of the New York Library, 2016).

There are many growth and group portraits in the photographer's collections. Ukrainian men and women appear in front of the camera in traditional costumes or work clothes according to their activities. Their poses are static: they sit or stand against the backdrop of a natural landscape or their own backyard. The face usually has a serious emotion with a pensive look, often the props for shooting are working equipment, such as pitchforks, buckets and more. The obligatory attribute is hats, or jewellery in the form of a wreath for girls, or handkerchiefs for women. From these seemingly minor details, we can learn more about the life of Ukrainians of that time, in particular women, draw conclusions about their preferences and views on beauty. It seems that the standard of beauty at that time was a working woman who performed a large amount of work. Nevertheless, she looked neat and emphasized her own charms with ribbons, braided braid, wreath, etc. She dressed in a rather restrained traditional Ukrainian outfit, which was necessarily divided into everyday and festive.

In 1873, "a student of Kyiv photographer F. K. de Mesera, Włodzimierz Wysocki (Polish: Włodzimierz Wysocki) - a Polish poet and photographer-artist" started his photo studio in Kyiv (Cherkaska, 2017).

"Therein 1884 Olena Pchilka brought thirteen-year-old Lesya Ukrainka to the countryman, photographer and poet", who immortalized the young poetess in Ukrainian dress, writes Cherkas$\mathrm{ka} \mathrm{H}$. (2017). If you look at the portrait, you will see a young girl with a massive wreath and many ornaments on her neck, dressed in an embroidered shirt, which testifies to the festivity and emphasizes the importance of photography. The reason for creating the photo was the first published poem of the poet. The portrait is made on a usual light background on a breast because of what, even all braid of the model didn't fit in a frame, the look is directed past the camera. This portrait is typical of the photo studio of that period.

The photographer's work includes a similar portrait of Sofiia Starytska, also in festive traditional Ukrainian clothes. That speaks to the rarity of such a phenomenon as photography at the time. Photos were taken only at significant events and formal clothes were worn for such an occasion. In 1886, immediately after the wedding, Ivan Franko and his wife Olha Khoruzhynska were photographed by V. Vysotskyi on the advice of the Polish writer Eliza Ozheshko. Olha appears in the photo, not in an embroidered shirt and wreath, but in a longclosed dress with buttons and minimalist jewellery on her neck, on her head, she has a hat as a reflection of the fashion of the end of the 19th century.

J. Khmelevskyi (1849-1924) from Poltava photographed in many genres. As 
a portraitist, he "left a legacy of images of cultural figures" (Trachun, 2010). He preserved the landscapes of places associated with the life of M. V. Gogol. But his genre scenes, where he reflected the Ukrainian everyday life are the most impressive. If we look at his photo of Ukrainian women of the early 20th century, we will see that they do not differ much from the portraits of V. Vysotskyi in concept, because the models are dressed mainly in traditional festive Ukrainian clothes, but differ in format. In photos, girls or women often appear in full length with a picturesque background and props, much attention is paid not only to the image of a girl but also to the details.

A prominent representative of twentiethcentury foreign photographers was British Christina Broom, "who was probably the first woman press photographer" (Christina Broom).

One of the most iconic images taken by Christina during the rally on July 23, 1910, in Hyde Park, is the image of the organizer of the suffragettes' Charlotte "Charlie" Marsh. In the picture, a woman in a long dress and a hat is depicted at full height. She stands confidently among the predominantly male crowd, carrying a large silk flag of the Women's Socio-Political Union (WSPU). Her gaze is concentrated straight on the camera, her figure is straight, her arms are lowered to the bottom, one of which is slightly set aside and the other holds the base of the flag. Christina Broome has many photos of protests and marches for women's freedom. Her models reflect the mood of an era that is in anticipation of major changes, including the coming war, which would also find its place in the author's photographs. The photo was focused on covering military and social events that covered almost the whole world.
Day by day the art developed. That development included photography. The era of cinema was coming, where women transformed into different characters, tried on different outfits, the style became an integral part of the portrait. A striking example is the portraits of the famous Kyiv resident Anna Stan. The actress poses in a photo with makeup and glamorous dresses with pearl feathers and various sequins. (An ambitious woman from Kiev, 2018).

At the same time, on the Internet, you can find portraits of the star in Ukrainian clothes. They are characterized by freedom of posture and the presence of light makeup on the face of the girl.

World War II displaced portrait by intensively developing genre and reportage shooting of wartime and life of society in that period.

Later, after the tragic events, fashion photography appeared among women's portraits, which had a tendency to develop since the 1920s.

There are portraits that should be done only in a studio, as evidenced by the work of American photographers such as Irving Penn and Richard Avedon. The name of Richard Avedon is known to all who themselves with photography. His works are familiar to everyone: black and white, a minimum of extra objects in the frame - only people who look closely at the viewer.

There is no hesitation that it was Avedon who became the legislator of a new genre in which fashion photography was closely intertwined with real life. As a result of such a combination of models with faceless dolls became real. Due to the reality of life, the characters were elegant and still glamorous. One of the famous photographs of this genre is a picture of the famous model Davy, who wearing a dress 
by Yves Saint Laurent poses among African elephants (Photographer Richard Avedon. The genius of a portrait, 2015).

In addition to a bright, aesthetically pleasing photograph, there appeared a photograph that contained a certain protest, a psychological message, and ignored the rules of "beautiful pictures". American photographer Diana Arbus became a representative of this trend in photography. She was visited by nudists, circus performers, and transgender people, throughout her work. While most Americans were idealists with strong family values, Diana Arbus highlighted marginalized communities (called "freaks") that also existed at the time. In her pictures, the imperfect and incomprehensible for most comes to the fore. It is impossible to consider Arbus exclusively as a master of deviations' shooting. After all, the peculiarity of her talent was the ability to find scary and terrifying, repulsive and abnormal in the usual scenes. At the same time, Diana shot freaks, physically extraordinary people and other social eccentrics in a completely ordinary situation, emphasizing their humanity, but also a constant internal tension. In her works, Arbus emphasized the totalitarianism of habitual norms, their cruelty and limitations (Diana Arbus - the strange and addictive master of marginal photography).

Social photography, which is designed to reflect the life of Soviet society, is spreading widely, at this time in Ukraine.

Later, photographers began to move away from the Soviet interpretation of photography That was done by Viktor Marushchenko, in Ukraine. He believed that photography should be observed much wider than in the Ukrainian context. His students noted that he had a vision of a contemporary artist. His collection includes portraits of famous cultural figures and many photographs by artist Mariia Pryimachenko. If we look at the photo portraits of Mariia, we will understand that they differ in the liveliness of the moment. Moreover, they are not staged, as was customary to photograph earlier (Khomenko and Syvets, 2020).

"The new generation of photographers, which received a boost for rapid growth with political and national thaw (Ukrainian poetic cinema), was destined to exist in times of stagnation". At that time, there was a group "Time", which went even more radically in the interpretation of the photo portrait and naked shooting manly ("body" as a protest) in the works of Mykhailov, Tubalev, Malovanyi, Pavlov (2019).

An artistic portrait explores a personality of a model. This is how the pictures characterize modern views on beauty. Photographs acquire naturalness and freedom from the usual canons that correspond to the spirit of the time (Lewinsky and Magnus, 1982b).

"If we consider the concept of portrait in the classical sense, it is, above everything, a psychology of a person, its emotion, history", says art critic Victoriia Mironenko (Hlushko, 2019). The critic notes that a certain humanistic message and idea is enough to "express an emotional component and make an impression". Here is what the art critic says about modernity: "today, in 2019, meaning is more important than form in which portrait is made. Nowadays, we live in an era of postmodernism, when the concept of genre is erased. There is simply an environment in which there are photographic images. When this genre appeared in photography, it was studio photography. Then the creative intelligentsia argued with photographers that such photos do not reflect the 
emotions and character of a man. Some beginners still believe that for a portrait it is enough just to take a picture of a beautiful girl on a background of a wall. But this is not the case" (Hlushko, 2019).

Modern women strive for independence, her interests are not different from the interests of men. She has become stronger and able to solve problems on her own, and all that leaves an imprint on a woman appearance. In the nowadays world, women hold positions that were previously exclusively male. There are many women leaders. However, a woman remains a woman when it comes to her career, household chores or business. She retains her femininity, individuality, beauty. This is what the photographer aims to convey to the audience. In addition, the author seeks to reveal other qualities independent of the social role of women.

Painting is a combination of specific feelings and emotions, and photography is a moment of reality, a part of life shown by a photographer to express his impression of an event or a person. Photo is primarily designed to reflect a specific moment. The most successful pictures are often those that seem to embody a keen sense of reality. This is not available to any other visual means. Nowadays, there are classic forms of portraits and completely new ones that were inaccessible to photographers of the past. The portrait uses the techniques of subject and landscape, and abstract photography, contributing to interpenetration and blurring of the boundaries of these genres. Both the growing availability of photography and the current state of culture play a role.

Nowadays, a new one is being formed on the basis of old forms. However, art critics note that the tendency to abandon the genre purity of the portrait, which originated more than a century ago, and now continues to determine its development. What photo portrait will be in the future is not known for sure, but the fact that it will remain an eternal document of human nature and life is clear today.

\section{Conclusions}

During the study of the female portrait subject of different times, many sources of information were processed. The creating of the article is based on the study of works by both foreign and national authors (Hlushko M., 2019, L. F. VolkovLannit., 1974, Trachun O., 2010, Khomenko A. and Syvets L., 2020, Christina Broom, Lewinskyi J. and Magnus M., 1982 and others). The main characteristics of the portrait of a woman from authenticity to the present were analyzed. The concept of female beauty in photography was considered. The history of the origin and formation of the female portrait in photography was studied. The development of the female photo portrait from the past to the present was traced. There are many ways in which a photo can show the main thing in the image of a model - the face. Depending on the task, a photographer is free in his work and can present it in the usual way, as an integral part of appearance or highlight it in close-up, giving the picture a different character. The concept of beauty is quite subjective, but when the standard of beauty becomes widespread, it reflects the characteristics of a certain era, becoming a valuable object of study. Photo portrait has developed over a long period, acquiring the characteristics of its time, in fact documenting history. As a woman was and is an integral part of society, a woman's portrait reflects the history of life, culture, values not only of models but also of those who photograph them. 
After all, each photo portrait is the result of communication between at least two people. A detailed analysis of the factors influencing the formation of this genre of photography, with the help of theoretical analysis identified factors that affect the development of female portraiture, outlined its specifics and features. On the basis of the studied data the comparison of photo portraits of women of different times, since the first one in history has been carried out.

The important role of a female photo portrait in the art of photography has been established, its peculiarity and importance have been proved.
This study does not exhaust the completeness of the entire theme of women's portraits from authentic to nowadays, due to its significant informational and territorial breadth, covering a period of more than a century. That leaves a wide field for further researches. It is worth noting the popularity of the subject, because in every country, town or village lived and live women and next to them there is an art of photography, which is constantly evolving, changing and acquiring more and more features and creating new documents of history in the form of portraits.

\section{REFERENCES}

Ambitcioznaia kievlianka [An ambitious woman from Kiev], 2018. Livelnternet. [online] 22 May 2018. Available at: <https://kulturologia.ru/blogs/210518/39035/> [Accessed 10 May 2020] Arkhivamy Niu-Yorkskoi biblioteky. Unikalni svitlyny ukraintsiv, zrobleni frantsuzom u kintsi 19 stolittia (FOTO) [Archives of the New York Library. Unique photos of Ukrainians taken by a Frenchman in the late 19th century (PHOTOS)], 2016. Reporter. [online] 13 January 2016. Available at: <https://report.if.ua/istoriya/arhivamy-nyu-jorkskoyi-biblioteky-unikalnisvitlyny-ukrayinciv-zrobleni-francuzom-u-kinci-19-stolittya-foto/> [Accessed 12 May 2020].

Cherkaska, H., 2017. "V. Vysotskyi zupynyv myttievosti" ["V. Vysotsky stopped the moments"]. UaModna. [online] Available at: <https://uamodna.com/articles/v-vysocjkyy-zupynyvmyttevosti/> [Accessed 10 May 2020]

Christina Broom, Press Photographer, 1916. Google Arts \& Culture. [online] Available at: <https:// artsandculture.google.com/exhibit/igICxvmu81GRJA> [Accessed 20 January 2020].

Diana Arbus - strannyi i pritiagatelnyi master marginalnoi fotografii [Diana Arbus - the strange and addictive master of marginal photography]. Photogora. [online] Available at: <https://fotogora.ru/diana-arbus-strannyy-i-prityagatelnyy-master-marginalnoy-fotografii/> [Accessed 12 May 2020].

Dzhuliia Margaret Kameron - angliiskii fotograf viktorianskoi epokhi [Julia Margaret Cameron English photographer of the Victorian era], 2016. Cameralabs. [online] Available at: <https:// cameralabs.org/11077-dzhuliya-margaret-kameron-anglijskij-fotograf-viktorianskoj-epokhi> [Accessed 10 May 2020].

Fotograf Richard Avedon (Richard Avedon). Genii portreta [Photographer Richard Avedon. The genius of a portrait], 2015. Nasmotrennost. [online] 7 October 2015. Available at: <http://www. paninphotoschool.ru/articles/?art=69> [Accessed 01 May 2020].

Hlushko, M., 2019. Svitlo, kamera, portret! Shcho (ne) tak z suchasnoiu portretnoiu fotohrafiieiu - poiasniuie mystetstvoznavytsia [Light, camera, portrait! What (not) so with 
modern portrait photography - explains art critic]. Kufer. [online] Available at: <https://kufer. media/lyudy/svitlo-kamera-portret/> [Accessed 10 May 2020].

Khomenko, A. and Sivetc, L., 2020. "On pytalsia smotret na fotografiiu vzgliadom sovremennogo khudozhnika". Vspominaem Viktora Marushchenko i ego luchshie raboty [He tried to look at photography with the eyes of a modern artist." We remember Viktor Marushchenko and his best works]. Hromadske UA. [online] 29 September 2020. Available at: <https://hromadske. ua/ru/posts/on-pytalsya-smotret-na-fotografiyu-vzglyadom-sovremennogo-hudozhnikavspominaem-viktora-marushenko-i-ego-luchshie-raboty> [Accessed 11 May 2020].

Lewinsky, J. and Magnus, M., 1982a. Osnovy fotoportreta [Photography Basics]. In: The Book of Portrait Photography. BY (RUS) 1. [e-book]. London: A Dorling Kindersley Book, pp.1-22. Available at: <https://epdf.pub/the-book-of-portrait-photography-by-rus-1-.html> [Accessed 22 January 2020].

Lewinsky, J. and Magnus, M., 1982b. Sovremennyi fotoportret [Contemporary photographic portrait]. In: The Book of Portrait Photography. BY (RUS) 5. [e-book]. London: A Dorling Kindersley Book, pp.70-78. Available at: <https://epdf.pub/the-book-of-portrait-photography-by-rus-5html> [Accessed 22 January 2020].

Pavlova, T., 2019. Do istorii kharkivskoi shkoly fotohrafii: hrupa "Vriemia" [To the history of the Kharkiv school of photography: group "Time"]. Korydor. [online] 30 June 2019. Available at: <http://www.korydor.in.ua/ua/context/11657.html> [Accessed 11 May 2020].

Pervyi $v$ istorii zhenskii fotoportret [The first ever female portrait], 2018. [online] Available at: <https://zen.yandex.ru/media/odnovremenno/pervyi-v-istorii-jenskii-fotoportret5aa1438c9d5cb381312d80c0> [Accessed 28 April 2020].

Sofiia, 2019. Istoriia fotoportreta [The history of the photo portrait]. PostScriptum. [online] Available at: <http://www.iterra.org.ua/fotografija/istorija-fotoportreta.html> [Accessed 10 May 2020].

Sova, 2019. Kyevskaia shkola fotohrafyy. Liuis Kerroll: kazkar i fotohraf [Kiev School of Photography. Lewis Carroll: storyteller and photographer]. Kyivska Shkola Fotohrafii. [online] 07 June 2019. Available at: <https://www.photoschool.kiev.ua/fotoklub/stati/175-lewiscarroll> [Accessed 10 May 2020].

Trachun, O., 2010. Zolotyi vik ukrainskoi fotohrafii [The golden age of Ukrainian photography]. Prime excursion bureau. [online] Available at: <http://primetour.ua/uk/company/articles/1. html> [Accessed 15 May 2020].

Volkov-Lannit, L.F., 1974. Iskusstvo fotoprtreta [The art of photography]. 2nd ed. Moscow: Iskusstvo. 


\title{
ЖІНОЧИЙ ПОРТРЕТ У ФОТОМИСТЕЦТВІ: ВІД АВТЕНТИКИ ДО СЬОГОДЕННЯ
}

\author{
Світлана Котляр ${ }^{1 a}$, Ірина Заспа ${ }^{2 a}$ \\ ${ }^{1}$ заслужений діяч мистецтв України, професор кафедри тележурналістики та майстерності актора; \\ e-mail: ilanit1925@gmail.com; ORCID:0000-0002-4855-8172 \\ ${ }^{2}$ магістрант кафедри кіно-, телемистецтва; \\ e-mail: duymovochkaira@gmail.com; ORCID: 0000-0003-0648-1901 \\ а Київський національний університет культури і мистецтв, Київ, Україна
}

\begin{abstract}
Анотація
Мета дослідження - проаналізувати жіночий фотопортрет, поняття жіночої краси в фотографії, історію виникнення та становлення жіночого портрета у фотомистецтві. Простежити розвиток жіночого фотопортрета від минулого до сучасності. Встановити роль жіночого фотопортрета у мистецтві фотографії, довести його особливість, значущість. Методологія дослідження полягає у застосуванні таких методів: теоретичного - аналіз поняття жіночої краси у фотопортреті, історії розвитку жіночого портрета у фотографії; емпіричного - дослідження взаємозв'язків між жіночими фотопортретами різних часів; порівняння - зіставлення сучасних та автентичних фотопортретів. У процесі пізнавального синтезу та узагальнення відмінних та подібних рис жіночих фотопортретів різних часів визначено особливі риси жіночого портрета. Наукова новизна. Вперше проаналізовано історію становлення жіночого фотопортрета від автентики до сьогодення на основі дослідження фотопортретів різних часів, проведено детальний аналіз чинників впливу на становлення цього жанру фотографії, окреслено його специфіку та особливості. Висновки. У статті проаналізовано портрет жінки у фотографії, поняття жіночої краси у різні відрізки часу. За допомогою аналізу історії розвитку й становлення жанру фотографії жіночого портрета, встановлено його роль у фотомистецтві. Визначено особливості жіночого фотопортрета як жанру фотомистецтва. Доведено його особливість та значущість. Детально опрацьовано чинники, які впливають на поняття жіночої краси у фотографії, розвиток жіночого фотопортрета та його особливості.
\end{abstract}

Ключові слова: портрет; жіночий фотопортрет; фотомистецтво; фотографія; мистецтво 


\title{
ЖЕНСКИЙ ПОРТРЕТ В ФОТОИСКУССТВЕ: ОТ АУТЕНТИЧНОСТИ К СОВРЕМЕННОСТИ
}

\author{
Светлана Котляр ${ }^{1 a}$, Ирина Заспа ${ }^{2 a}$ \\ ${ }^{1}$ заслуженный деятель искусств Украины, профессор кафедры тележурналистики \\ и мастерства актера; e-mail: ilanit1925@gmail.com; ORCID: 0000-0002-4855-8172 \\ ${ }^{2}$ магистрант кафедры кино-, телеискусства; \\ e-mail: duymovochkaira@gmail.com; ORCID: 0000-0003-0648-1901 \\ а Киевский национальный университет культуры и искусств, Киев, Украина
}

\begin{abstract}
Аннотация
Цель исследования - проанализировать женский фотопортрет, понятие женской красоты в фотографии, историю возникновения и становления женского портрета в фотоискусстве. Проследить развитие женского фотопортрета от прошлого к современности. Установить роль женского фотопортрета в искусстве фотографии, довести его особенность, важность. Методология исследования заключается в применении таких методов: теоретического - анализ понятия женской красоты в фотопортрете, истории развития женского портрета в фотографии; эмпирического исследование взаимосвязей между женскими фотопортретами разных времен; сравнения сопоставление современных и аутентичных фотопортретов. В ходе познавательного синтеза и обобщения отличных и сходных черт женских фотопортретов разных времен, определены особые черты женского портрета. Научная новизна. Впервые проанализирована история становления женского фотопортрета от аутентичности к современности на основе исследования фотопортретов разных времен, проведен детальный анализ факторов влияния на становление этого жанра фотографии, определена его специфика и особенности. Выводы. В ходе статьи проанализирован портрет женщины в фотографии, понятие женской красоты в разные отрезки времени. С помощью анализа истории развития и становления жанра фотографии женского портрета, установлена его роль в фотоискусстве. Определены особенности женского фотопортрета как жанра фотоискусства. Доказана его особенность и важность. Детально проработанные компоненты, факторы, которые влияют на понятие женской красоты в фотографии, развитие женского фотопортрета и его особенности.
\end{abstract}

Ключевые слова: портрет; женский фотопортрет; фотоискусство; фотография; искусство 